\title{
A COMPARATIVE STUDY OF PREOPERATIVE INTRA-INCISIONAL INFILTRATION OF CEFTRIAXONE VS. INTRAVENOUS CEFTRIAXONE FOR PREVENTION OF SURGICAL SITE INFECTIONS IN EMERGENCY CASES
}

\author{
Samir Anand ${ }^{1}$, Rajat Batra ${ }^{2}$, Bhavinder Arora ${ }^{3}$, Sanjeev Atwal ${ }^{4}$, R. S. Dahiya ${ }^{5}$ \\ ${ }^{1}$ Assistant Professor, Department of General Surgery, PGIMS, Rohtak. \\ 2Junior Resident, Department of General Surgery, PGIMS, Rohtak. \\ ${ }^{3}$ Associate Professor, Department of General Surgery, PGIMS, Rohtak. \\ ${ }^{4}$ Ex. Resident, Department of General Surgery, PGIMS, Rohtak. \\ 5Senior Professor and Unit Head (Retired), Department of General Surgery, PGIMS, Rohtak.
}

\section{ABSTRACT}

Operations without sepsis remain an unfulfilled goal since the introduction of antisepsis by Lister who made it a realistic objective. ${ }^{1}$ Wound infection accounts for nearly one-fourth of the total number of nosocomial infections. ${ }^{2}$ Even though the complete elimination of wound infection is not possible, a reduction of the wound infection rate to a minimum level could have marked benefits in terms of both patient comfort and resources used.

\section{METHODS}

A total of 120 patients were randomized into two groups of 60 each. Controls Group A received single dose intravenous ceftriaxone $(1 \mathrm{gm})$, whereas test Group B received intra-incisional ceftriaxone given subcutaneously along the incision line preoperatively with single dose intravenous ceftriaxone $(1 \mathrm{gm})$. Patients in both groups received routine post-operative antibiotics in dirty, clean contaminated and contaminated cases. An intraoperative swab was taken and sent to Department of Microbiology where they inoculated in Blood agar and MacConkey's medium. The patients were seen on daily basis till the day of discharge from the hospital and followed up as outpatient basis once a week for 30 days. Discharge from patient's wound were collected and sent to Department of Microbiology for processing.

\section{RESULTS}

The rate of surgical site infection was more in Group A than Group B (25\% vs. 8.33\%). In Group B no cases of SSI was found in clean, clean contaminated and dirty group and 5 cases of SSI out of 24 were found in contaminated cases (20.83\%), whereas in Group A all wound class had SSI. Among the organisms cultured from various swabs taken, there was predominance of E. coli (75\%).

\section{CONCLUSION}

Pre-operative intra-incisional antibiotics reduce the rate of SSI in all wound classes. The higher concentration achieved at the incision site by the intra-incisional route theoretically makes it a better mode of administering prophylactic antibiotics.

\section{KEYWORDS}

Ceftriaxone, Intra-Incisional, Intravenous, SSI.

HOW TO CITE THIS ARTICLE: Anand S, Batra R, Arora B, et al. A comparative study of preoperative intra-incisional infiltration of ceftriaxone vs. intravenous ceftriaxone for prevention of surgical site infections in emergency cases. J. Evolution Med. Dent. Sci. 2016;5(64):4537-4541, DOI: 10.14260/jemds/2016/1036

\begin{tabular}{ll}
\hline INTRODUCTION & incisional antibiotic preoperatively has yielded much better \\
Wound infection is one of the major causes for increased post- & $\begin{array}{l}\text { results. The current study was undertaken to study the role of } \\
\text { intra-incisional antibiotics in combination with systemic }\end{array}$ \\
operative morbidity. In the very early phase, the antibiotics & $\begin{array}{l}\text { antibiotic on decreasing surgical site infection. }\end{array}$
\end{tabular}

already established wound infection. It was subsequently discovered that antibiotics need to be administered preoperatively for the prophylaxis of wound infection. One among such methods is the intra-incisional infiltration of prophylactic antibiotic along the incisional site. The antibiotics were initially infiltrated along the incision site just before suturing the skin incision at the end of the surgical procedure. Even though this resulted in good results in terms of reduction of wound infection, but the infiltration of prophylactic intra-

Financial or Other, Competing Interest: None.

Submission 30-05-2016, Peer Review 27-07-2016,

Acceptance 03-08-2016, Published 10-08-2016.

Corresponding Author:

Dr. Rajat Batra,

Junior Resident,

Department of General Surgery,

Pt. B. D. Sharma PGIMS, Rohtak.

E-mail: surgery.advanced@gmail.com

DOI: $10.14260 /$ jemds/2016/1036

\section{METHODS}

Study Design: This study was conducted in the Department of General Surgery in collaboration with Department of Microbiology in our institution. Patients for the study were selected from among those admitted in surgical emergency. The study was approved by the Institutional Ethical Committee.

Patient Eligibility and Selection: A total of 120 patients were selected according to the following criteria. Patients of all age $<90$ years, operative procedures which lasted for less than 3 hours, procedure performed under general anaesthesia or regional anaesthesia, operating team remains same throughout the procedure.

Exclusion Criteria: Patients undergoing surgery with surgical site infection of previous operative procedure, patients with infection at other sites, patients with diabetes mellitus and prosthetic implant and patients at risk of 
developing endocarditis were excluded because of inability to be randomized into various groups. The patients were seen on a daily basis till the day of discharge from the hospital and followed up as outpatient basis once a week for 30 days. An informed and written consent was taken from all the patients included in the study.

\section{Randomization and Trial Flow}

Patients were selected randomly and randomized into two groups of 60 each. Control Group A received single dose intravenous ceftriaxone ( $1 \mathrm{gm})$, whereas test Group B received intra-incisional ceftriaxone (1 gm) subcutaneously along the incision line just before incision along with single dose intravenous ceftriaxone (1 gm). Same brand of ceftriaxone was used throughout the study. Patients in both groups received routine post-operative antibiotics covering gram positive, gram negative and anaerobes in dirty, clean contaminated and contaminated cases. Intraoperative swabs moistened with sterile peptone water were taken from surgical wound infection before closure and inoculated into glucose broth.

The swabs were sent to Department of Microbiology, where they inoculated in Blood agar and MacConkey's medium. All the bacterial growths were identified as per standard recommendations and antibiotics prophylaxis of relevant isolate was done by Kirby Bauer technique. The patients were seen on a daily basis till the day of discharge from the hospital with the reference to pulse, temperature, fluid exudates from wound, pain, redness, local swelling. Thereafter patients were followed up as outpatient basis once a week for 30 days. Discharge from wound of patients were collected and sent to the Department of Microbiology for processing as mentioned earlier.

Statistical Analysis: Data was analysed using SPSS version 20. Two groups were analysed using ' $T$ ' test for quantitative analysis and chi square test for qualitative analysis. Significant difference was considered when $p$ value was less than 0.05 .

\section{RESULTS}

In Group A, number of patients having age of $<50$ years were 49 and those of $>50$ years of age were 11 and they were comparable to Group B having 47 patients $<50$ years and 13 patients $>50$ years of age. The rate of surgical site infection was more in age group $<50$ years in both the groups as shown in table below.

\begin{tabular}{|c|c|c|c|c|}
\hline Age & Group & Number & SSI & Percentage \\
\hline \multirow{2}{*}{$<50$} & $\mathrm{~A}$ & 49 & 12 & 24.48 \\
\cline { 2 - 5 } & $\mathrm{B}$ & 47 & 4 & 8.5 \\
\hline \multirow{2}{*}{$>50$} & $\mathrm{~A}$ & 11 & 3 & 27.27 \\
\cline { 2 - 5 } & $\mathrm{B}$ & 13 & 1 & 7.6 \\
\hline \multirow{2}{*}{ Table 1: Distribution of Patients on the Basis of Age } \\
having SSI in Both Groups \\
\hline
\end{tabular}

Total male patients were 51 vs. 18 and female patients were 9 vs. 42 for Group A and B respectively. The rate of SSI were more among male than female patients in both the groups (25.49\% vs. $22.2 \%$ for Group A and $11.11 \%$ vs. $6.66 \%$ for Group B) and that was statistically significant with $p$ value of 0.037 .

Overall rate of SSI in Group B (test) were found to be nearly three times lower in Group A (Control) and that was statistically significant with $p$ value of 0.014 .

\begin{tabular}{|c|c|c|c|}
\hline Group & Cases & SSI (NO) & \% \\
\hline A & 60 & 15 & 25 \\
\hline B & 60 & 05 & 8.3 \\
\hline \multicolumn{4}{|c|}{ Table 2: The Overall Rate of SSI in Both Groups } \\
\hline
\end{tabular}

In Group B no cases of SSI was found in clean, clean and contaminated and dirty group and 5 cases of SSI out of 24 were found in contaminated cases (20.83\%), whereas in Group A all wound class had SSI.

\begin{tabular}{|c|c|c|c|c|}
\hline \multirow{2}{*}{ Group } & \multicolumn{2}{|c|}{ A } & \multicolumn{2}{c|}{ B } \\
\cline { 2 - 5 } & \multicolumn{2}{|c|}{ SSI/Total \% } & \multicolumn{2}{c|}{ SSI/Total \% } \\
\hline Clean & $1 / 4$ & 25 & $0 / 1$ & 0 \\
\hline $\begin{array}{c}\text { Clean and } \\
\text { contaminated }\end{array}$ & $4 / 31$ & 12.90 & $0 / 31$ & 0 \\
\hline Contaminated & $8 / 22$ & 36.66 & $5 / 24$ & 20.83 \\
\hline Dirty & $2 / 3$ & 66.66 & $0 / 4$ & 0 \\
\hline Total & $15 / 60$ & 25 & $05 / 60$ & 8.3 \\
\hline
\end{tabular}

Table 3: Distribution of SSI in Each Wound Class in Both the Groups

\begin{tabular}{|c|c|c|c|c|}
\hline 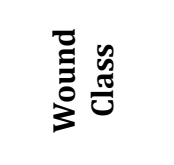 & ఖ & 导 & 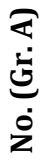 & $\begin{array}{l}\text { Ð } \\
\dot{0} \\
\dot{0} \\
z\end{array}$ \\
\hline Clean & CA oesophagus & $\begin{array}{c}\text { Feeding } \\
\text { jejunostomy }\end{array}$ & 4 & 1 \\
\hline \multirow{11}{*}{$\begin{array}{c}\text { Clean } \\
\text { Contaminated }\end{array}$} & Appendicitis & Appendicectomy & 17 & 13 \\
\hline & $\begin{array}{c}\text { Peptic } \\
\text { perforation } \\
\text { (Fresh Cases) }\end{array}$ & $\begin{array}{l}\text { Gram patch } \\
\text { repair }\end{array}$ & 4 & 8 \\
\hline & $\begin{array}{l}\text { Blunt trauma } \\
\text { abdomen }\end{array}$ & $\begin{array}{c}\text { Splenography + } \\
\text { PL }\end{array}$ & 1 & - \\
\hline & $\begin{array}{c}\text { Obstructed } \\
\text { ventral hernia }\end{array}$ & $\begin{array}{l}\text { Herniotomy } \\
\text { with RA with } \\
\text { defect repair }\end{array}$ & 2 & - \\
\hline & Gunshot injury & RA (Jejunum) & 2 & 1 \\
\hline & Stab Abdomen & Splenectomy & 4 & - \\
\hline & SAIO & $\begin{array}{c}\text { Adhesiolysis + } \\
\text { RA }\end{array}$ & - & 2 \\
\hline & UB perforation & Repair & - & 1 \\
\hline & Blunt trauma & CFA repair & 1 & - \\
\hline & UB stone & $\begin{array}{c}\text { Open } \\
\text { cystostomy }\end{array}$ & - & 1 \\
\hline & $\begin{array}{c}\text { Enteric } \\
\text { perforation }\end{array}$ & $\begin{array}{c}\text { Primary repair } \\
\text { ileum }\end{array}$ & - & 5 \\
\hline \multirow{5}{*}{ Contaminated } & $\begin{array}{c}\text { (Burst } \\
\text { appendix) }\end{array}$ & Appendicectomy & 6 & 14 \\
\hline & $\begin{array}{c}\text { Peptic } \\
\text { perforation } \\
\text { (Old } \\
\text { contaminated } \\
\text { cases) } \\
\end{array}$ & $\begin{array}{l}\text { Gram patch } \\
\text { repair + PL }\end{array}$ & 1 & 6 \\
\hline & $\begin{array}{c}\text { Enteric } \\
\text { perforation } \\
\text { (Old } \\
\text { contaminated } \\
\text { cases) }\end{array}$ & $\begin{array}{l}\text { Ileostomy, end } \\
\text { (2) \& loop ( } 3 \text { ) }\end{array}$ & 5 & - \\
\hline & Gut gangrene & $\begin{array}{l}\text { Gut resection + } \\
\text { end ileostomy }\end{array}$ & 1 & 1 \\
\hline & $\begin{array}{l}\text { Strangulated } \\
\text { ventral hernia }\end{array}$ & $\begin{array}{c}\text { RA + } \\
\text { herniotomy + } \\
\text { defect repair }\end{array}$ & - & 2 \\
\hline
\end{tabular}




\begin{tabular}{|c|c|c|c|c|}
\hline & SAIO & RA ileum & 1 & - \\
\hline & $\begin{array}{c}\text { Intussusceptio } \\
n\end{array}$ & RA ileum & 2 & - \\
\hline & GB perforation & $\begin{array}{c}\text { PL+ } \\
\text { Cholecystectom } \\
y\end{array}$ & 1 & - \\
\hline & Gun shot & $\begin{array}{l}\text { RA (Jejunum) + } \\
\text { splenectomy (2) } \\
\text { Liver repair (2) }\end{array}$ & 4 & - \\
\hline & $\begin{array}{l}\text { Paraduodenal } \\
\text { hernia (obst.) }\end{array}$ & Adhesiolysis & 1 & - \\
\hline & $\begin{array}{l}\text { Blunt trauma } \\
\text { abdomen }\end{array}$ & $\begin{array}{c}\mathrm{RA}+ \\
\text { splenectomy }\end{array}$ & - & 1 \\
\hline \multirow[b]{2}{*}{ Dirty } & Gut Gangrene & End jejunostomy & 3 & - \\
\hline & $\begin{array}{c}\text { Enteric } \\
\text { Perforation } \\
\end{array}$ & End ileostomy & - & 4 \\
\hline Total & & & 60 & 60 \\
\hline
\end{tabular}

SAIO = Subacute Intestinal Obstruction, UB = Urinary Bladder, GB = Gall Bladder, $\mathrm{CFA}=$ Common Femoral Artery, RA $=$ Resection Anastomosis, $\mathrm{PL}=$ Peritoneal Lavage

In both groups, maximum numbers of cases were of appendicectomy followed by peptic perforation, trauma and enteric perforation.

The rates of SSI also depend on the duration of operative procedures. In Group B the procedure that lasted for less than or equal to one hour, there was no cases of SSI. When it lasted for between one and two hours, SSI was seen in $15.3 \%$ and between two to three hours SSI was seen in $15.78 \%$. The rates of SSI was noted based on the duration of surgery was significant overall $(\mathrm{p}<0.011)$ in comparing surgeries which lasted less than one hour and those lasted between one to two hours and more. In Group A, SSI were seen irrespective of duration of surgery. In most of cases, SSI in both groups (13 vs. 3) was a superficial surgical infection, i.e. it was confined superficial to deep fascia. In Group B, one patient developed organ site infection due to multiple leaks and perforations. Swab cultures were taken from various factors mentioned, i.e. surgeon's glove, antiseptics, instrument trolley.

\begin{tabular}{|c|c|c|c|c|c|}
\hline $\begin{array}{c}\text { Organisms } \\
\text { Isolated }\end{array}$ & $\begin{array}{c}\text { SI } \\
\text { Swab }\end{array}$ & $\begin{array}{c}\text { OT } \\
\text { Swab }\end{array}$ & $\begin{array}{c}\text { OE } \\
\text { Swab }\end{array}$ & $\begin{array}{c}\text { AD } \\
\text { Swab }\end{array}$ & $\begin{array}{c}\text { P0 } \\
\text { Swab }\end{array}$ \\
\hline E. coli & 09 & 0 & 0 & 0 & 05 \\
\hline Klebsiella sp. & 00 & 0 & 0 & 0 & 02 \\
\hline $\begin{array}{c}\text { Pseudomonas } \\
\text { sp. }\end{array}$ & 03 & 0 & 0 & 0 & 00 \\
\hline $\begin{array}{c}\text { Staphylococcus } \\
\text { aureus }\end{array}$ & 01 & 0 & 0 & 0 & 00 \\
\hline \multicolumn{6}{|c|}{ Table 5: Organism Isolated from Various Swab } \\
Collected During the Operation \\
\hline
\end{tabular}

SI Swab - Surgical Incision site swab, OT- Operating Team swab, OE- Operating Equipment swab, AD swab - Antiseptic and Dressing material swab, PO- Post-Operative wound swab.

Among the organisms cultured from various swabs taken, there were predominance of gram negative organisms (75\%) as compared to gram positive organisms (25\%). Among the individual organism cultured, Escherichia coli was the commonest (75\%) followed by Pseudomonas aeruginosa (12.5\%), Klebsiella sp. (6.25\%) and staphylococcus aureus (6.25\%).

\begin{tabular}{|c|c|c|c|c|c|}
\hline $\begin{array}{l}\text { Sl. } \\
\text { No. }\end{array}$ & $\begin{array}{l}\text { Class of } \\
\text { Wound }\end{array}$ & Cases & SSI & Bacteria & SSI \\
\hline \multirow{2}{*}{1.} & \multirow{2}{*}{ Clean } & \multirow{2}{*}{4} & \multirow{2}{*}{1} & E. coli & 1 \\
\hline & & & & Sterile & 3 \\
\hline \multirow{2}{*}{2.} & \multirow{2}{*}{$\begin{array}{c}\text { Clean } \\
\text { Contaminated }\end{array}$} & \multirow{2}{*}{31} & \multirow{2}{*}{4} & E. coli & 4 \\
\hline & & & & Sterile & 27 \\
\hline \multirow{4}{*}{3.} & \multirow{4}{*}{ Contaminated } & \multirow{4}{*}{22} & \multirow{4}{*}{8} & E. coli & 5 \\
\hline & & & & Pseudomonas & 2 \\
\hline & & & & Staph aureus & 1 \\
\hline & & & & Sterile & 14 \\
\hline \multirow{3}{*}{4.} & \multirow{3}{*}{ Dirty } & \multirow{3}{*}{3} & \multirow{3}{*}{2} & E. coli & 1 \\
\hline & & & & Klebsiella & 1 \\
\hline & & & & Sterile & 1 \\
\hline & $\begin{array}{r}\text { ble 6: Distril } \\
\text { Co }\end{array}$ & no & ( & $\begin{array}{l}\text { Isolate am } \\
\text { A) }\end{array}$ & \\
\hline
\end{tabular}

\begin{tabular}{|c|c|c|c|c|c|}
\hline $\begin{array}{c}\text { Sl. } \\
\text { No. }\end{array}$ & Class of Wound & Cases & SSI & Bacteria & SSI \\
\hline 1. & Clean & 0 & 0 & Sterile & 0 \\
\hline 2. & $\begin{array}{c}\text { Clean } \\
\text { Contaminated }\end{array}$ & 32 & 0 & Sterile & 32 \\
\hline 3. & Contaminated & 24 & 5 & E Coli & 5 \\
\cline { 3 - 6 } & Dirty & 4 & 0 & Sterile & 19 \\
\hline 4. & Table 7: Distribution of Bacterial Isolate among & 4 \\
\hline \multicolumn{5}{|c|}{ Test Cases (Group B) } \\
\hline
\end{tabular}

\section{DISCUSSION}

Surgical Site Infection (SSI) is one of the commonest complications following surgery. The rate of SSI has been brought down considerably by the various aseptic measures and the use of prophylactic systemic antibiotics. There are some drawbacks associated with the use of systemic antibiotics like decreased concentration and fibrin matrix formation at the incision site, improper timing of administration of systemic antibiotics which led to the introduction of newer mode of administration of antibiotics, one of which is intra-incisional infiltration of antibiotics. This ensures a higher concentration of antibiotic at the incision site and better compliance.

In our study, there is significant decrease in SSI in both the groups. Overall rate of SSI in Group B (text) was found to be nearly three times lower than in Group A (control) as shown in Table No. 2 above. This is similar to study done by Dixon and Armstrong done with Cefamandole, in which 205 patients who underwent elective as well as emergency operations upon gastrointestinal tract were randomized into three groups; the control group not receiving any antibiotic and in the two test groups one received 1 gram of Cefamandole intravenously and the other intravenously and intra-incisionally. They found intra-incisional infiltration to be more efficacious than intravenous administration. ${ }^{3}$ On the other hand, study done by Greenall et al where the effect of intravenous and intraincisional Cephaloridine was compared and they found to be equally efficacious. ${ }^{4}$ The rate of SSI were not significantly different in their study between the two groups - major wound sepsis $(3.5 \%$ and $2.1 \%)$ and minor wound sepsis $(12.4 \%$ and $15.5 \%)^{4}$ In yet another study to see the efficacy of intraincisional antibiotics, patients were randomized to have antibiotic Amoxicillin/Clavulanic acid injected intravenously single dose at the time of induction of anaesthesia or infiltrated 
subcutaneously just before incision. They found incidence of SSI was considerably lower in the group given the antibiotics in the abdominal wall. 5

\begin{tabular}{|c|c|c|c|c|c|}
\hline$\frac{\vec{Z}}{\tilde{E}}$ & $\frac{\Xi}{త ్}$ & ن̃ & 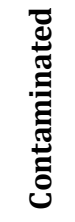 & $\stackrel{\vec{n}}{a}$ & 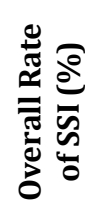 \\
\hline $\begin{array}{c}\text { Horen } \\
\text { et al, } \\
\text { USA }^{6} \\
\end{array}$ & 2.1 & 3.3 & 6.1 & 7.4 & 4.75 \\
\hline $\begin{array}{c}\text { Kaya et } \\
\text { al } \\
\text { Turkey }\end{array}$ & 3.4 & 9.2 & 9.7 & 27.5 & 12.8 \\
\hline $\begin{array}{l}\text { Sangrasi } \\
\text { et al, } \\
\text { Pakistan }^{8} \\
\end{array}$ & 5.4 & 12.3 & 36.3 & 40 & 13 \\
\hline $\begin{array}{l}\text { Kamat } \\
\text { et al } \\
\text { India }^{9} \\
\end{array}$ & 5.4 & 35.5 & 77.8 & & 30.7 \\
\hline $\begin{array}{l}\text { Thesis } \\
\text { study } \\
\text { (Group B) }\end{array}$ & 0 & 0 & 8.3 & 0 & 8.3 \\
\hline
\end{tabular}

In the current study, the overall infection rate in Group B is $8.3 \%$ and the individual distribution showed the similar increasing trend of infections as the degree of contamination increases. In Western countries, studies reported infection rate of clean (1.5-3.7\%), clean and contaminated (3-4\%), contaminated wounds (8.5\%), dirty wounds (28-40\%) even in large studies conducted by Horen et al, ${ }^{6}$ with 60,000 patients as a sample size. However, in the developing nations like Middle East countries, Latin America and Indian subcontinent the rate are much higher. A study in Peru in 1998 showed the overall incidence rate to be $26.7 \% .^{10}$ In India studies shows higher infection rates like a study in Goa in a teaching hospital showed infection rate of $24 \% .{ }^{9}$ In a similar study by Subramanian et al in AIIMS estimated infection rate of $24.8 \% .11$ This difference in the rate of SSI in Indian study group in developed countries is probably due to poor nutritional status, increased incidence of infective disease and operating environment in Indian population. In this study the rate of SSI in contaminated cases is high, which may be due to contamination in the dressing material, reusable gloves or hospital environment.

Duration of surgery was also identified as a risk factor for SSI, regardless of wound infection. In 1985, Haley et al ${ }^{12}$ found that surgeries longer than 2 hours' duration were predictive of wound infection. The incidence of wound infection increased 3 folds (2.1 to $6.4 \%$ ), as operation went from 2 to 4 hours in duration.

In our study, gram negative bacteria accounted for about $89 \%$ of the isolated organisms with the commonest bacteria being Escherichia coli (57.1\%), Klebsiella (18.9\%), Pseudomonas $(11.4 \%)$. While there are only four cases of gram positive bacteria (Staphylococcus aureus $8.6 \%$ recovered out of 56 infected patients). Studies in India by Kamat et al, ${ }^{9}$ in India where $79.33 \%$ of isolates were gram negative bacteria; pseudomonas being the commonest one followed by staphylococcus pyogenes. In another study by Khan et al,13 Escherichia coli was the commonest pathogen found (25\%) followed by Pseudomonas aeruginosa (20.83\%) and coagulase positive staphylococci (19.04\%) in general surgical setup.

In our study, gram negative organisms were the causative organisms for all the SSI reported. In a study done earlier, control of gram positive organisms by antibiotics and their relative lack of efficacy against gram negative variety led to an increased incidence of SSI by these organisms.14 Thus prophylactic antibiotics should cover gram negative organism and so third generation cephalosporins should be the ideal choice. This was the basis for use of ceftriaxone as the drug of choice for the present study.

\section{CONCLUSION}

Pre-operative intra-incisional antibiotics reduce the rate of SSI in all wound classes. The higher concentration achieved at the incision site by the intra-incisional route theoretically makes it a better mode of administering prophylactic antibiotics.

\section{REFERENCES}

1. Burdon DW. Principles of antimicrobial prophylaxis. World J Surg 1986;6(3):262-7.

2. Haley RW, Culver DH, White JW. The nationwide nosocomial infection rate: a new need for vital statistics. Am J Epidemiol 1985;121(2):159-67.

3. Dixon JM, Armstrong CP, Duffy SW. A randomized prospective trial comprising the value of intravenous and intra-incisional cefamandole in reducing post-operative sepsis after operations upon the gastrointestinal tract. Surg Gynecol Obstet 1984;158(4):303-7.

4. Greenall MJ, Atkinson JE, Pollock AV. Single dose antibiotic prophylaxis of surgical wound sepsis: which route of administration is best? A controlled clinical trial of intra-incisional against intravenous cephaloridine. J Antimicrobial Chemo 1981;7(3):223-7.

5. Pollock AV, Evans M, Smith GM. Intra-incisional intraparietal augmentin in abdominal operation. Ann R Coll Surg Eng 1989;71(2):97-100.

6. Horan TC, Culver DH, Gaynes RD. Surgical wound infection rates by wound class, operative procedure and patients risk index. Am J Surg 1991;91(3B):152S-7S.

7. Kaya E, Yetim I, Dervisoglu A, et al. Risk factors for and effect of one year surveillance program on surgical site infection at a university hospital in Turkey. J Surg Infect 2006;7(6):519-26.

8. Sangrasi AK, Leghari AA, Memon A, et al. Surgical site infection rate and associated risk factors in elective general surgery at public sector medical university in Pakistan. Int Wound J 2008;5(1):74-8.

9. Kamat US, Fereiira AMA, Kulkarni MS, et al. A prospective study of surgical site infections in a teaching hospital in Goa. Indian Journal Surg 2008;70(3):120-4.

10. Meakins JL. Surgical infection 1972-1977: a quarter century of progress introduction. World J Surg 1988;22(2):115-7.

11. Subramanian KA, Prakash A, Shriniwas, et al. Postoperative wound infection. Ind J Surg 1973;57-64.

12. Haley RW, Culver DH, Morgan WM. Identifying patients with risk of surgical wound infection. Am J Epidemiol 1980;111:472-80. 
13. Khan SA, Rao PGM, Rao A, et al. Survey and evaluation of antibiotic prophylaxis usage in surgery wards of tertiary level institution before and after the implementation of clinical guidelines. Indian J Surg 2006;68(3):150-6.
14. Ayliffe GA. Role of the environment of the operating suite in surgical wound infection. Rev Infect Dis 1991;13(Suppl 10):800-4. 